\title{
Wyzwania w budownictwie i nauczaniu inżynierów budownictwa
}

\author{
Ewa Blazik-Borowa
}

\begin{abstract}
Katedra Mechaniki Budowli, Wydziat Budownictwa i Architektury, Politechnika Lubelska, e-mail:e.blazik@pollub.pl
\end{abstract}

Streszczenie: W pracy omówiono problem zakresu kształcenia inżyniera budownictwa $\mathrm{w}$ okresie intensywnego rozwoju technologii, wzrostu wymagań w odniesieniu do obiektów budowlanych oraz wzrostu oczekiwań społecznych w odniesieniu do osób pełniących samodzielne funkcje techniczne. W artykule omówiono przykładowe rozwiązania zmniejszające energochłonność budynków, tematykę projektowania i wznoszenia budynków wysokich z uwzględnieniem aspektów zrównoważonego rozwoju, technologie rewitalizacji obiektów zabytkowych, które straciły swoje funkcje w związku z przemianami społecznymi, zasady współpracy pomiędzy branżami oraz problem odpowiedzialności inżyniera budownictwa za zespoły, którymi kieruje. Wykazano, że studia powinny przekazywać taki zasób wiedzy, aby z jednej strony uświadomić inżynierowi, jak ważny jest jego zawód dla społeczeństwa a $\mathrm{z}$ drugiej strony mogły być podstawą do dalszego samodzielnego poszerzenia wiedzy.

Słowa kluczowe: kwalifikacje zawodowe, problemy inżynierskie, nowoczesne technologie, etyka zawodu inżyniera budownictwa.

\section{Wprowadzenie}

Celem artykułu jest pokazanie rozwoju budownictwa na wybranych przykładach rozwiązań konstrukcyjnych i technologicznych oraz wynikającej z tej sytuacji konieczności zmian w nauczaniu przyszłych inżynierów budownictwa. Przed przystąpieniem do prezentacji propozycji nauczania na II stopniu studiów na kierunku Budownictwo na specjalności Konstrukcje Budowlane i Technologie Ekologiczne należy się zastanowić nad tym czego należy oczekiwać od magistra inżyniera budownictwa, który ma pełnić samodzielną funkcję techniczną w budownictwie w zawodzie zaufania publicznego czyli takiego, który wpływa na nasze otoczenie oraz decyduje o naszym codziennym bezpieczeństwie.

W babilońskim Kodeksie Hammurabiego, zapisanym na steli około 1750 roku p.n.e., wymienionych jest kilka wybranych zawodów i są to sędziowie, lekarze, agenci handlowi, kapłani, weterynarze oraz właśnie „budowniczy”. W odniesieniu do wymienionych zawodów w Kodeksie zapisano oficjalne wysokości honorariów, kary za postępowanie niezgodne $z$ etosem zawodowym oraz kary i odszkodowania przewidziane za błędne wykonywanie zawodu. Zawody te charakteryzują się tym, że społeczeństwo, korzystając z usług danej branży, powinno móc zaufać wykonawcy pracy. Do zawodów zaufania publicznego zalicza się zawody o szczególnym charakterze z punktu widzenia zadań publicznych i ważnych z punktu widzenia interesu publicznego. W przypadku budownictwa to zaufanie dotyczy przede wszystkim tego, że obiekty z których korzystamy są bezpieczne a użyte materiały prawidłowo dobrane. To słowo ,prawidłowo” oznacza tutaj dobór zarówno ze względów 
ekonomicznych jak i technologicznych a ostatnio uwzględniający także aspekty zrównoważonego rozwoju. Może ta tematyka nie miałyby tak dużego znaczenia, gdyby nie powszechna obecność budownictwa w naszym życiu. Wszystkie dziedziny gospodarki korzystają z obiektów budowlanych a każdy człowiek korzysta z budynków jako swojego miejsca zamieszkania, pracy lub budynków użyteczności publicznej. Ten artykuł dotyczy głównie budownictwa kubaturowego, ale wymienione aspekty dotyczą również budownictwa komunikacyjnego i inżynierii sanitarnej.

Fakt, że inżynier budownictwa jest zawodem zaufania publicznego oznacza, że społeczeństwo ma prawo oczekiwać od inżyniera budownictwa, że w swojej pracy będzie kierował się zasadami etycznymi i będzie brał pod uwagę dobro publiczne we wszystkich formach swojej działalności, tzn. podczas wykonywania swojego zawodu, podczas zarządzania zespołem, w kontaktach z kooperantami, współpracownikami a w szczególności klientami. Już sam fakt, że inżynier budowlany wykonuje zawód zaufania publicznego wymaga od niego poszanowania środowiska i myślenia o przyszłości kolejnych pokoleń, a więc musi posiadać świadomość stosowania zasad zrównoważonego rozwoju. Z drugiej strony trzeba zdawać sobie sprawę, że są ludzie których nie stać na nowe drogie technologie. Należy więc poszukiwać rozwiązań ekologicznych, ale i ekonomicznych, oszczędzających nie tylko energię, ale również zasoby kieszeni klientów. Biorąc to pod uwagę można powiedzieć, że inżynier budownictwa powinien posiadać trzy cechy: świadomość ekologiczną, wiedzę i umiejętności inżynierskie oraz kompetencje społeczne (rys. 1). Zestaw przedmiotów specjalności Konstrukcje Budowlane i Technologie Ekologiczne został dobrany w taki sposób, aby pokryć wymienione kompetencje. Dobierając przedmioty kierowano się również tym, że absolwent powinien posiadać rzetelną i uporządkowaną wiedzę, która pozwoli mu na realizację obiektów budowlanych zgodnie z najnowszymi trendami. Przyjęto, że znaczną część podstaw teoretycznych opanował na studiach I stopnia. Natomiast celem studiowania na II stopniu studiów jest rozszerzeniem posiadanej wiedzy i umiejętności oraz ukształtowanie świadomości znaczenia zawodu inżyniera budownictwa.

W pracy zaprezentowano przykłady nowych technologii i rozwiązań konstrukcyjnych oraz problemów społecznych, z którymi w swojej pracy spotyka się inżynier budownictwa. Na tej podstawie zobrazowano główne cechy programu i planów studiów studiów na kierunku Budownictwo, które będą gwarantowały przydatność absolwentów dla społeczeństwa.

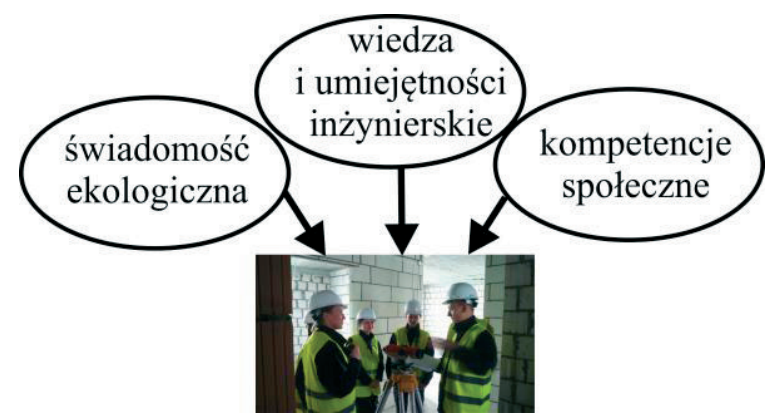

Rys. 1. Cechy inżyniera budowlanego jako przedstawiciela zawodu zaufania publicznego 


\section{2. Świadomość ekologiczna}

\subsection{Informacje ogólne}

Budownictwo jest działem gospodarki, który ma bardzo silny wpływ na środowisko naturalne. Wszystkie etapy cyklu życia obiektu budowlanego (rys. 2) są związane zarówno z wpływem na otoczenie jak i energochłonnością. To oddziaływanie jest związane z tym, że z jednej strony tworząc nowe obiekty zmieniamy nasze otoczenie, zmieniając jednocześnie środowisko przyrodnicze, na które składają się warunki geologiczne, warunki geomorfologię, rzeźba terenu, sieć hydrograficzna, gleba, zasoby naturalne, rozmieszczenie flory i fauny, itd. Z drugiej strony budownictwo jest najbardziej energochłonnym działem gospodarki. Według autorów prac [1] i [2] tak, jak pokazano na rys. 3, w Polsce i w Europie zużycie energii w budynkach mieszkalnych i usługowych w 2005 roku wyniosło odpowiednio około $61 \%$ i $55 \%$ całkowitego zapotrzebowania na energię. $Z$ analizy rys. 4 wynika, że ponad $88 \%$ zużycia energii w cyklu życia obiektu budowlanego przypada w Polsce na eksploatację czyli udział zużycia energii w budownictwie w całkowitym zużyciu energii w kraju można szacować na ok. 68\%. Dlatego bardzo ważne jest, aby absolwenci mieli świadomość jak ich praca wpływa na środowisko oraz w jaki sposób mogą zmniejszyć to oddziaływanie poprzez stosowanie nowoczesnych materiałów i technologii. Poniżej podane zostaną dwa przykłady nowych rozwiązań, zmniejszających zużycie energii w budynku.

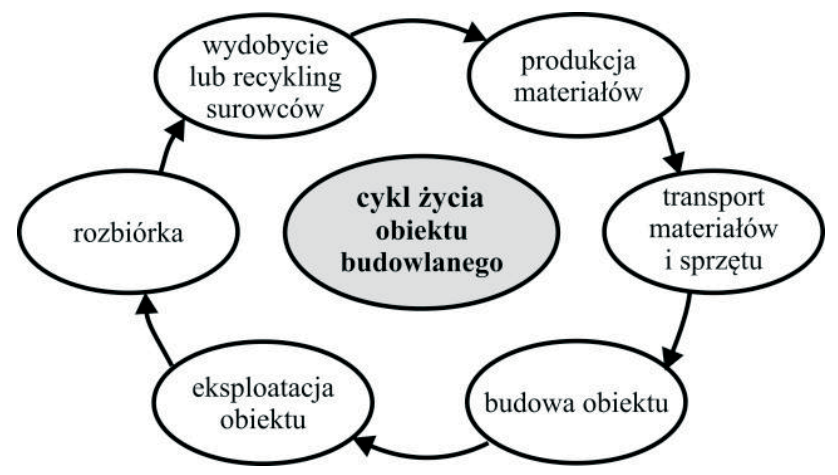

Rys. 2. Cykl życia obiektu budowlanego (LCA)

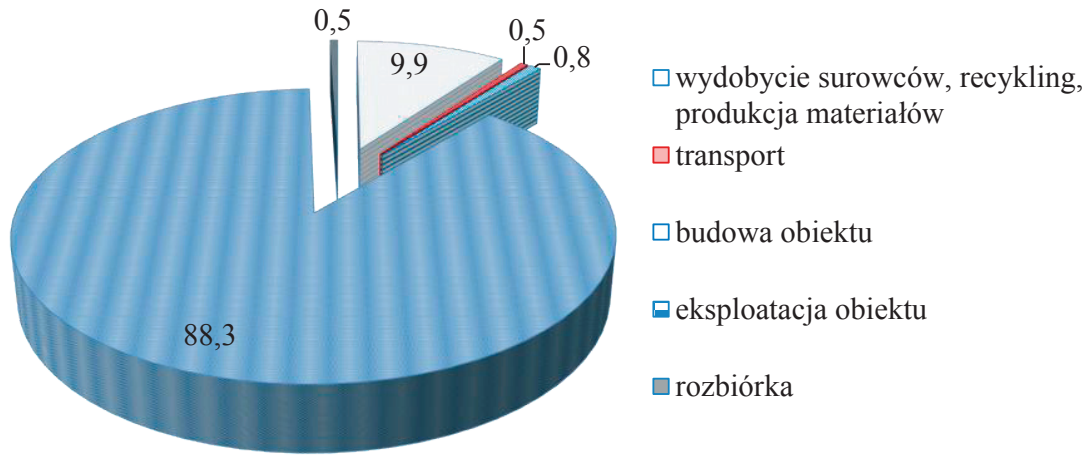

Rys. 3. Procentowy udział zużycia energii w budownictwie w Polsce w poszczególnych etapach cyklu istnienia budynku na podstawie pracy [1] 


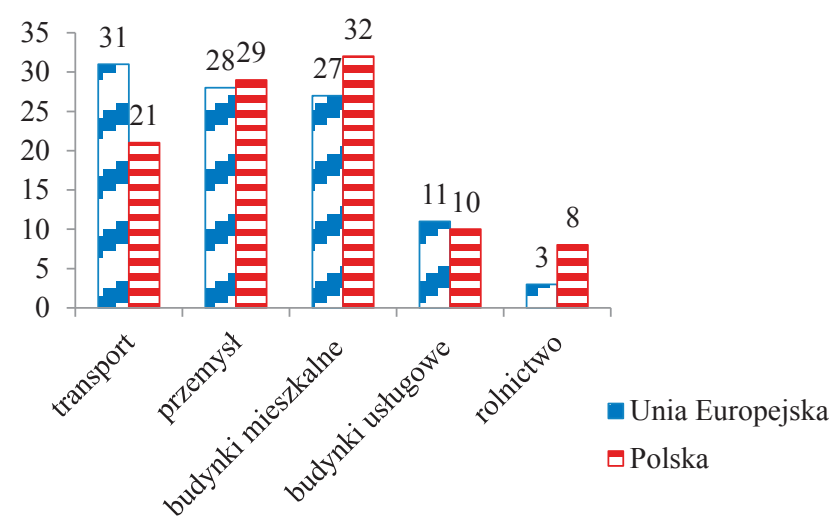

Rys. 4. Procentowy udział zużycia energii w poszczególnych działach gospodarki w 2005 za pracami [1], [2]

\subsection{Przykłady rozwiązań zmniejszających energochłonność budynku}

Obecnie takie problemy jak kształtowanie architektoniczno-urbanistyczne z uwzględnieniem aspektów zrównoważonego rozwoju, technologie budownictwa ekologicznego, badanie efektywności energetycznej materiałów budowlanych, wykorzystania różnych metod i zasobów komputerowych do oceny wpływu budowy na środowisko, metody i możliwości recyklingu czyli problemy, które są związane ze zmniejszeniem energochłonności cyklu istnienia budynku (rys. 2), są głównymi kierunkami badań w dyscyplinie budownictwo i powinny być podstawowymi elementami programów kształcenia inżynierów budownictwa. Efektem tego typu badań są na przykład materiały zmiennofazowe, nazywane również skrótem PCM (ang. Phase-Change Materials). Idea tego typu materiałów polega na tym, że materiał budowlany (beton, gips, beton komórkowy) zawiera mikrokapsułki, które zmieniają fazę $\mathrm{z}$ ciekłej $\mathrm{w}$ stałą $\mathrm{i}$ odwrotnie podczas zmian temperatury w ciągu doby. W nocy, kiedy temperatura otoczenia jest niższa od temperatury wewnątrz pomieszczenia, zawartość mikrokapsułek przechodzi z fazy ciekłej do stałej, oddając w ten sposób ciepło. Etap ten trwa do momentu kiedy temperatura otoczenia jest odpowiednio niższa niż temperatura zmiany fazy PCM-u z ciekłej na stałą. W dzień kiedy temperatura na zewnątrz budynku wzrasta energia cieplna najpierw jest pochłaniana przez przemiany fazowe w PCM czyli zmianę fazy ze stałej na ciekłą. W ten sposób powietrze wewnętrzne nie jest ogrzewane. Przykładami takich materiałów są np. gipsowe płyty, produkowane przez firmę BASF, które zawierają materiał zmiennofazowy o nazwie Micronal ${ }^{\circledR}$ PCM. Mikrokapsułki w tym materiale zawierają przede wszystkim parafinę. Lista publikacji, omawiających możliwości stosowania PCM w budownictwie jest bardzo długa i są to np. prace [3], [4] i [5].

Bardzo ciekawym rozwiązaniem, zwiększających oszczędność energii, są okna elektrochromiczne czyli takie, w których kolor lub tylko zmatowienie szyby zmienia się pod wpływem przepływu prądu elektrycznego. Szyba w elektrochromicznym oknie jest pokryta folią, zawierającą warstwy, które przewodzą prąd, oraz warstwy, które zmieniają barwę pod wpływem przepływającego prądu elektrycznego. Dzięki temu szyba w oknie może być przezroczysta, przepuszczająca światło i ciepło, lub matowa blokująca dostęp energii do wnętrza budynku. Naukowcy eksperymentują obecnie z aktywnymi warstwami zawierającymi nikiel i tlenek wolframu oraz jony litu. Zmiana koloru szyb (ich przyciemnianie) polega na przyłożeniu niewielkiego napięcia, które wymusza przeniesienie jonów litu pomiędzy warstwami [6]. 
W pracy [7] na przykładzie budynku Wydziału Sztuki i Nauk Humanistycznych Uniwersytetu w Coimbrze (rys. 5) wykazano pozytywny wpływ stosowania szyb elektrochromicznych. Dla elewacji wschodniej uzyskano zmniejszenie rocznego zużycia energii w zakresie od $3.7 \%$ do $24.4 \%$, oraz na zachodniej elewacji od $5.3 \%$ do $23.9 \%$. Podobne wielkości zostały podane w pracy [8] gdzie podano, że dzięki zastosowaniu okien z kontrolą przepuszczalności światła można uzyskać zmniejszenie zużycia energii od 10\% do $24 \%$.

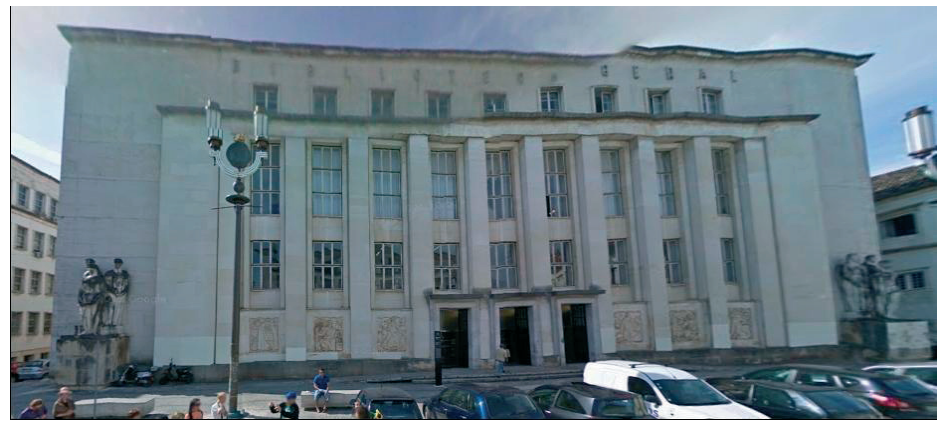

Rys. 5. Budynek Wydziału Sztuki i Nauk Humanistycznych Uniwersytetu w Coimbrze (Portugalia), źródło: google map

Zmiany w technologiach wykonania szyb ze szczególnym uwzględnieniem okien elektrochromicznych zostały opisane w pracy [8]. Jednak jest to dziedzina, która nadal się rozwija, ponieważ obecnie bardzo trudno uzyskać jednolitą zmianę w szybach na bardzo dużej powierzchni a koszt wykonania takich okien jest kilkukrotnie wyższy niż okien z szybami tradycyjnymi.

Powyżej wybrano tylko przykłady kierunków badań, które mają doprowadzić do zmniejszenia zużycia energii. Takich działań jest znacznie więcej, o czym świadczy duża popularność konferencji o tematyce, związanej z energooszczędnością obiektów budowlanych.

Poza wyżej zasygnalizowanymi aspektami energooszczędnośvi poszanowanie środowiska, to także taka lokalizacja nowych obiektów, która nie będzie zagrażała florze i faunie i nie będzie zmieniała warunków gruntowo-wodnych, to wykorzystywanie materiałów, przy produkcji których ogranicza się emisję $\mathrm{CO}_{2}$ do środowiska, itd.

\section{Wiedza i umiejętności inżynierskie}

Omówione problemy w poprzednim punkcie wymagają od inżyniera budownictwa, z jednej strony, kompetencji miękkich, dotyczących umiejętności poszanowania środowiska, ale, z drugiej strony, właśnie możliwość budowy nowych obiektów z uwzględnieniem aspektów zrównoważonego rozwoju wymaga wiedzy i umiejętności inżynierskich. Stosowanie nowych technologii wymaga wiedzy oraz reżimu technologicznego. Najprostszym przykładem są budynki drewniane, w których nieprawidłowe przygotowanie materiału prowadzi do bardzo dużych problemów eksploatacyjnych.

O wiedzy inżyniera budownictwa decydują tendencje jakie są widoczne w budownictwie czyli wykorzystanie technologii i materiałów ekologicznych, budowa obiektów wysokich, rewitalizacja obszarów poprzemysłowych, ochrona zabytków i utrzymanie obecnych zasobów infrastruktury kubaturowej i komunikacyjnej. Tak jak w poprzednim punkcie, tak i tutaj zostaną przedstawione wybrane problemy. 


\subsection{Budynki wysokościowe}

Każdy inżynier konstruktor marzy, aby w życiu przynajmniej raz zaprojektować lub uczestniczyć w budowie budynku o skomplikowanej konstrukcji. Takie możliwości dają nam budynki wysokościowe.

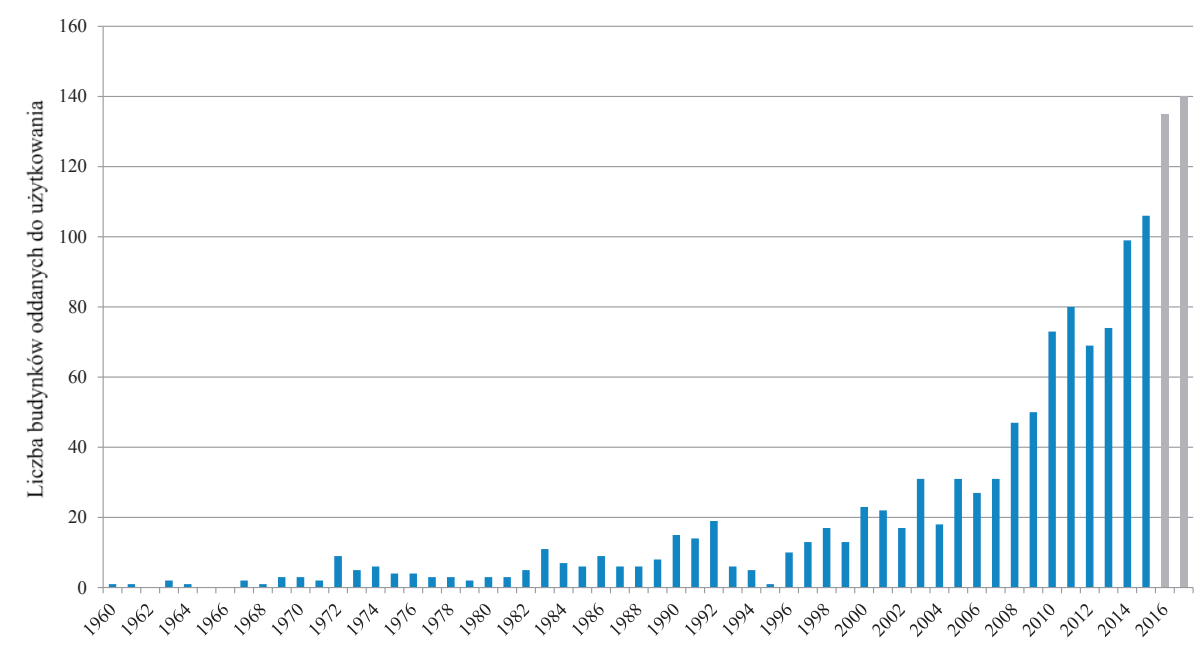

Rys. 6. Liczba budynków wysokościowych oddanych do użytkowania w poszczególnych latach świecie [9]

Na świecie widać wyraźną tendencję do budowania obiektów wysokich (rys.6), chociaż te najwyższe buduje się przede wszystkim obecnie w Azji (rys. 7). Budynki wysokie są wyzwaniem dla wszystkich branż budowlanych. Konstrukcja takich budynków musi zapewnić przeniesienie obciążeń pionowych czyli najczęściej ciężaru, statycznych i dynamicznych oddziaływań poziomych spowodowanych przez wiatr, dynamicznych obciążeń parasejsmicznych lub sejsmicznych oraz obciążeń termicznych. Posadowienie takiego obiektu powinno być wykonane tak, aby grunt przeniósł obciążenia pionowe, oraz aby budynek nie miał możliwości obrotu. Ten ostatni element zapewnia się między innymi przez budowę kilku kondygnacji podziemnych. Budowa obiektów najczęściej w gęstej zabudowie miejskiej wymaga zastosowania metod organizacji pracy, które uwzględnią brak miejsca na składowanie materiałów, wymagania technologiczne stosowanych materiałów i rozwiązań konstrukcyjnych (np. czas uzyskiwania wytrzymałości przez beton lub montaż prefabrykatów z ich prawidłowym uszczelnieniem) i wysokość wykonywanych prac.

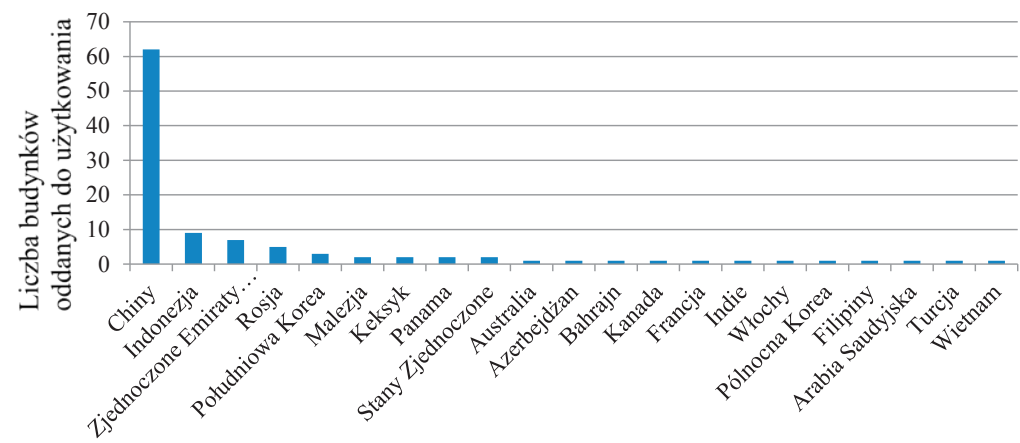

Rys. 7. Liczba budynków oddanych do użytkowania w roku 2015 z podziałem na kraje [9] 
Bezpieczeństwo i komfort użytkowania takiego budynku zapewniają instalacje sanitarne i elektryczne połączone w systemy zarządzania budynkiem BMS (Building Management System). Takie systemy mogą być mniej lub bardziej rozbudowane i zarządzać instalacją wodno-kanalizacyjną, instalacją elektryczną, oświetleniem, wentylacją, systemem ochrony przeciwpożarowej, systemem bezpieczeństwa, komunikacją i systemem thumienia drgań.

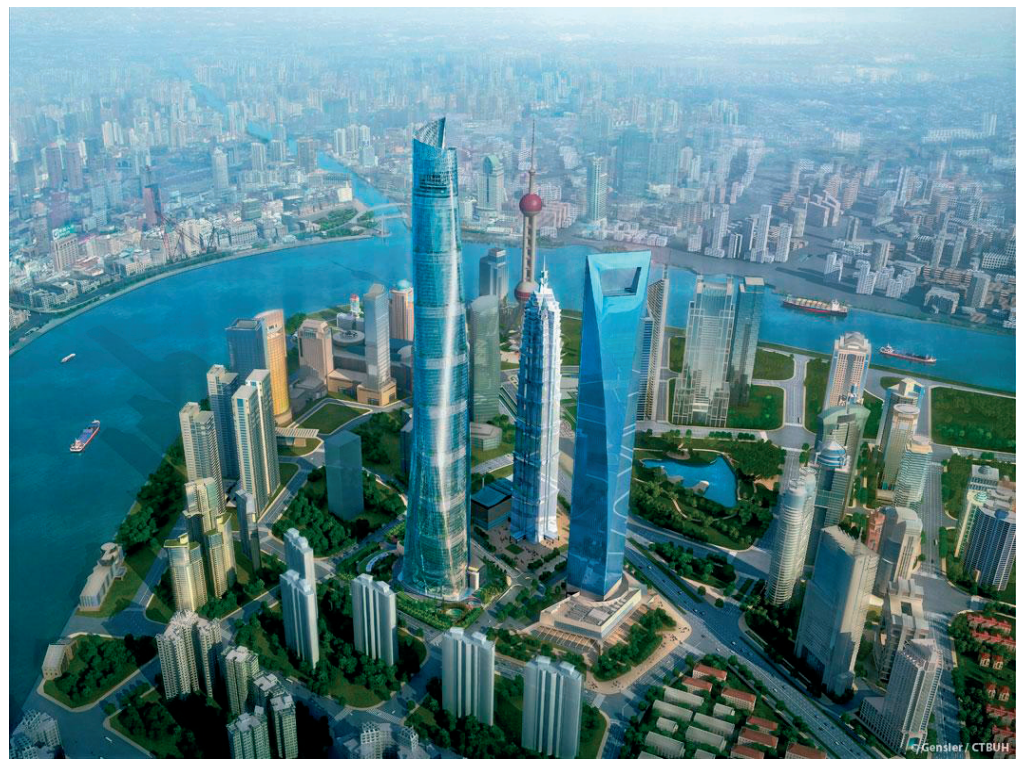

Rys. 8. Shanghai Tower, http://skyscrapercenter.com/building/shanghai-tower/56

Elewacje budynków wysokich mogą służyć do mocowania modułów fotowoltaicznych. Przykładami budynkami, gdzie zamocowano ogniwa tego typu, są budynek Cooperative Insurance Tower w Manchester (Wielka Brytania) i Pearl River Tower w Guanzhou (Chiny). Także przykładem wykorzystania wielu innych ciekawych rozwiązań w budynku wysokościowym jest Shanghai Tower w Szanghaju (Chiny) o wysokości 632m oddany do użytkowania w 2015 roku. Budynek ten został opisany w pracy [10] z wykorzystaniem dokumentacji, zamieszczonej w pracy[11]. Poniższe informacje także są podawane na podstawie tych dwóch pozycji literaturowych.

Obiekt został zaprojektowany z dziewięciu nałożonych na siebie, walcowatych budynków. Każdy z budynków ma swoją elewację, a oprócz tego wszystkie budynki są otoczone wspólną fasadą. W przestrzeni pomiędzy poszczególnymi walcami usytuowano dziewięć atriów. Kształt budynku został dobrany na podstawie badań w tunelu aerodynamicznym. W Szanghaju występują bardzo często porywiste wiatry oraz tajfuny. Dzięki wykonaniu wizualnego skrętu na elewacji, zwężeniu budynku ku górze i zaokrągleniu naroży zredukowano obciążenie wiatrem o $24 \%$ co pozwoliło na $32 \%$ zmniejszenie kosztów budowy konstrukcji budynku. Praca [11] podaje, że obiekt jest wybudowany z wykorzystaniem materiałów kompozytowych. Projektanci w ten sposób określili konstrukcję, składającą się żelbetowego trzonu i ze stalowych słupów oraz żelbetowych belek jako konstrukcji stropu. 
Budynek jest zaopatrzony w thumik masowy o masie 1000 ton umieszczony w podstawie budynku w celu zmniejszenia drgań i poprawę komfortu użytkowania budynku.

W prezentowanym budynku zamontowano instalację sanitarną, która poza tradycyjnym zastosowaniem miała za zadanie przekierowanie wody opadowej oraz wody wstępnie używanej do innych celów do spłuczek w toaletach. Dzięki temu uzyskano zmniejszenie zużycia wody o 40\%. Zużycie energii zmniejszono w budynku o $21 \%$ między innymi poprzez generowanie energii przez 270 turbin wiatrowych w budowanych w fasadę budyn$\mathrm{ku}$.

Powyższy przykład jest bardzo spektakularny, ale w Polsce też buduje się wysokie budynki i warto na etapie projektowania przewidzieć problemy, które mogą pojawić się podczas eksploatacji. Podczas podejmowania decyzji o lokalizacji budynku należy też pamiętać o sąsiednich obiektach. Budowa nowego obiektu zmienia oddziaływania środowiskowe na inne obiekty, np. może doprowadzić do dodatkowych osiadań gruntu lub zmiany charakteru działania wiatru. Jednak wszystkich zagadnień, związanych z budową obiektów wysokościowych, nie można opisać w jednej pracy a jedynie zasygnalizować i zobrazować ich złożoność.

\subsection{Rewitalizacja obszarów poprzemysłowych}

Obecnie w wielu miastach Polski i Europy można wyodrębnić obszary poprzemysłowe. Jest to efekt przemian gospodarczych i społecznych, trwających od XIX w. W XIX w. powstało wiele dzielnic przemysłowych w miastach oraz powstały nowe ośrodki przemysłowe, które bardzo szybko się rozwijały. Takim przykładem jest Łódź, gdzie osada $\mathrm{z}$ kilkuset mieszkańcami $\mathrm{w}$ ciągu stu lat zamieniła się $\mathrm{w}$ miasto przemysłowe $\mathrm{z}$ liczbą ludności wynoszącą 672 tys. w 1939r. Odejście od ciężkiego przemysłu, wprowadzanie zasad zrównoważonego rozwoju i rozwój świadomości konieczności poszanowania środowiska spowodowało, że zakłady przemysłowe są od 50 lat XX w. zamykane. W ten sposób do zagospodarowania pozostały obiekty przemysłowe o bardzo atrakcyjnym położeniu i dodatkowo z ochroną konserwatorską.

Rewitalizacja tych obiektów, w tym przebudowa i zmiana funkcji powinny być poprzedzone rozpoznaniem warunków gruntowych, oceną stanu technicznego obiektu oraz możliwości spełnienia wymagań Rozporządzenia [12] czyli bezpieczeństwa konstrukcji, bezpieczeństwa pożarowego, bezpieczeństwa użytkowania, odpowiednich warunków higienicznych i zdrowotnych oraz ochrony środowiska, ochrony przed hałasem i drganiami, oszczędności energii i odpowiedniej izolacyjności cieplnej przegród. Problematyka ta szczegółowo została opisana np. w pracy [13].

Kolejny etap to przygotowanie metody przebudowy obiektu, która uzależniona jest od wymienionych wcześniej elementów i od zaleceń konserwatorskich. Bardzo często wyburza się wnętrze obiektu, pozostawiając zewnętrzną skorupę, tworzoną przez elewację i dach. Przykładem takiego postępowania jest ponad 110 letni budynek po kasynie wojskowym w Hrubieszowie (rys. 9). Co prawda nie jest to przykład rewitalizacji obszarów przemysłowych, ale też jest związany ze zmianami społecznymi a mianowicie ze zmniejszeniem liczby żołnierzy w armii i ze zmianami funkcji obiektów wojskowych. Obiekt jest obecnie wykorzystywany jako restauracja z browarem i hotel. Fundamenty zostały podbite a zewnętrzne ściany z cegły pełnej zostały odrestaurowane (piaskowanie i zabezpieczenie powierzchni). Natomiast wewnątrz budynku pozostawiono jedynie główne elementy stropów opartych na ścianach zewnętrznych. Wewnątrz wybudowano nowe ściany konstrukcyjne, które wraz ze ścianami zewnętrznymi stanowią oparcie dla stropów żelbetowych. 


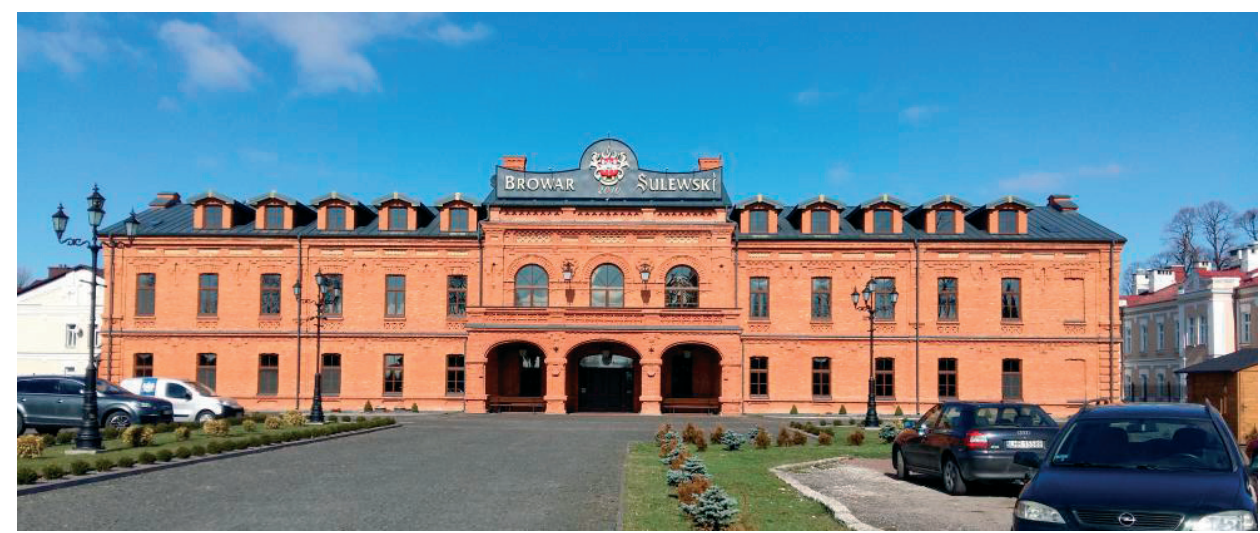

Rys. 9. Budynek po kasynie wojskowym w Hrubieszowie

Zmiana funkcji budynku nie zawsze wymaga całkowitego usunięcia wnętrza. Przykłady sposobu zagospodarowania, tzn. przebudowy wraz ze zmianą funkcji, są podane np. w pracy [14]. W tej pracy opisano typowe rozwiązania konstrukcyjne fabryk łódzkich i podano między innymi taką informację, że w Łodzi są obiekty, które jak najbardziej mogą być poddane rewitalizacji, ale są również parterowe hale kryte najczęściej dachami szedowymi, które nie nadają się do dalszej eksploatacji. Należy na to zwrócić uwagę, ponieważ pewna moda i brak świadomości inwestorów powoduje, że stawiane są przed inżynierami wymogi, których nie można spełnić. Oczywiście w pracy [14] pokazano także przykłady skutecznej rewitalizacji, tzn. omówiono sposób zaadaptowania czterokondygnacyjnego budynku tkalni Fryderyka Wilhelma Schweikerta do potrzeb dydaktyczno-laboratoryjnych Politechniki Łódzkiej. W obiekcie wykonano następujące prace [14]:

- zabezpieczenie elementów drewnianych przed korozją biologiczną,

- wzmocnienie stropów w celu zwiększenia ich nośności i zapewnienia bezpieczeństwa pożarowego, które polegało na zastosowaniu belek żelbetowych „otulających" z dwóch stron belki drewniane,

- wykonanie płyty żelbetowej o gr. 45mm na istniejącej podłodze drewnianej z kotwieniem w ścianach nośnych,

- zabezpieczenie stropów od spodu płytami karton-gips,

- ocieplenie budynku od wewnętrznej strony płytami MULTIPOR,

- typowe prace wykończeniowe.

Tego typu prace wymagają bardzo dużego doświadczenia. Jednak nowoczesne technologie zwiększają możliwości wykorzystania obiektów zabytkowych i poprzemysłowych i realizację większości wymogów rozporządzenia [12] oraz wymogów konserwatorskich.

\section{Kompetencje społeczne}

Rozporządzenie [15] wprowadziło od 2012 roku Krajowe Ramy Kwalifikacji w szkolnictwie wyższym. W zakresie wiedzy i umiejętności nie była to wielka rewolucja, ponieważ uczelnie techniczne zawsze kształtowały programy tak, aby przekazywać treści potrzebne w praktyce. Nowością było wprowadzenie kompetencji społecznych. Zawsze w dydaktyce rolą nauczyciela było nie tylko przekazywanie wiedzy, ale również wpajanie zasad etycznych. Jednak na uczelniach wyższych często mówiło się o tym, że studenci są osobami dorosłymi, których już nie należy wychowywać. Takie podejście nauczyciela 
akademickiego do studenta zmieniły zasady KRK a szczególnie kompetencje społeczne. Na Wydziale Budownictwa i Architektury na kierunku Budownictwo zapisano, że student [16]:

- „rozumie potrzebę uczenia się przez całe życie; potrafi inspirować i organizować proces uczenia się innych osób,

- ma świadomość ważności i rozumie pozatechniczne aspekty i skutki działalności inżynierskiej, w tym jej wpływu na środowisko, i związanej z tym odpowiedzialności za podejmowane decyzje,

- potrafi współdziałać i pracować w grupie, przyjmując w niej różne role,

- potrafi odpowiednio określić priorytety służące realizacji określonego przez siebie lub innych zadania,

- prawidłowo identyfikuje i rozstrzyga dylematy związane z wykonywaniem zawodu

- potrafi myśleć i działać w sposób kreatywny i przedsiębiorczy,

- ma świadomość roli społecznej absolwenta uczelni technicznej, a zwłaszcza rozumie potrzebę formułowania i przekazywania społeczeństwu, w szczególności poprzez środki masowego przekazu, informacji i opinii dotyczących osiągnięć techniki i innych aspektów działalności inżynierskiej; podejmuje starania, aby przekazać takie informacje i opinie w sposób powszechnie zrozumiały, z uzasadnieniem różnych punktów widzenia"

Poniżej przedstawione zostaną wybrane aspekty, które przewijają się w treściach kształcenia, ale które również są ważnymi nurtami zainteresowań naukowych nauczycieli WBiA i są powiązane ze społeczną rolą inżyniera budownictwa.

\subsection{Wspólpraca pomiędzy branżami budowlanymi}

Pokazane w poprzednich punktach problemy inżynierskie mogą być rozwiązane tylko i wyłącznie, jeżeli będą rozwiązywane przez zespoły, w których skład wchodzić będą specjaliści różnych branż budowlanych: architekci, konstruktorzy, instalatorzy, drogowcy, geodezji, geolodzy, itd. Kolejne branże podczas projektowania i budowy obiektu produkują znaczne ilości informacji, które muszą zostać zarchiwizowane i rozdystrybuowane pomiędzy wszystkimi branżystami na każdym etapie powstawania obiektu. W tym celu obecnie wprowadzany jest proces BIM (building information modeling).

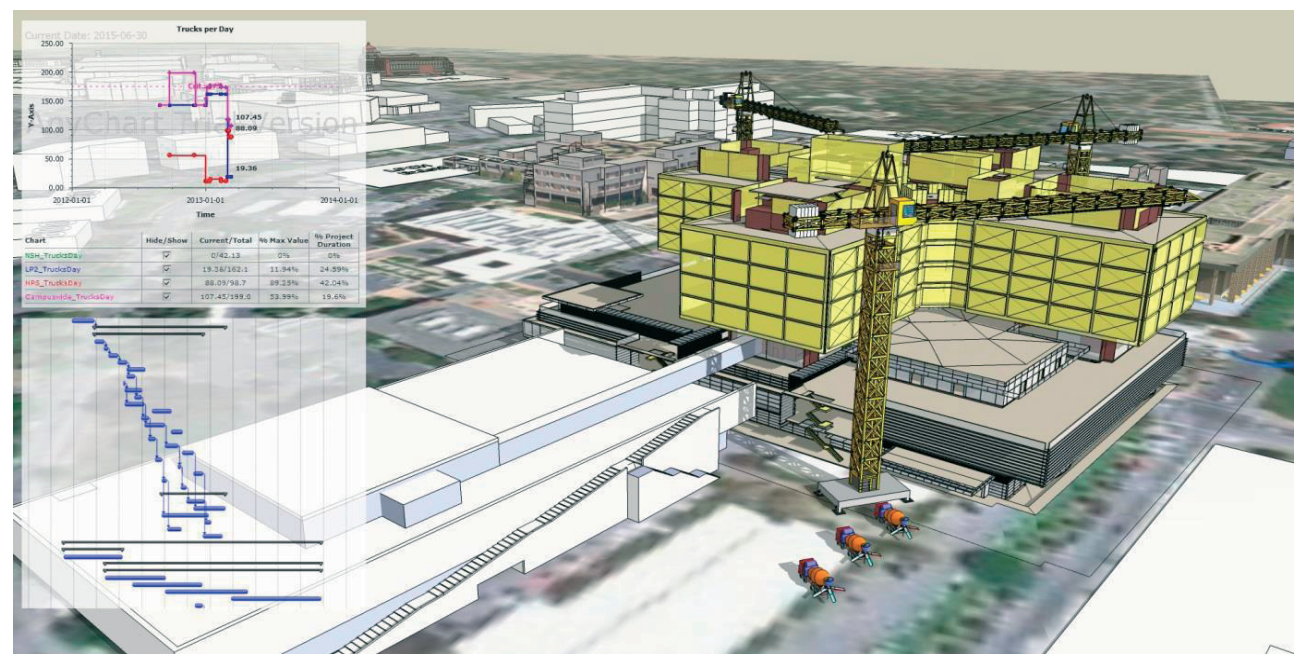

Rys. 10. Zobrazowanie idei procesu BIM na poziomie 4D [17] 
Filozofia tego procesu została opisana między innymi w pracy [17]. Opisując ideę stosowaniu procesu BIM w zarządzaniu procesem budowlanym używa się skrótów, które określają poziom BIM i są to:

- 2D - stosowanie technicznych rysunków dwuwymiarowych,

- 2D/3D - połączenie rysunków dwuwymiarowych z połączeniem projektowania w trójwymiarowego, w tym zarówno rysowania jak i wykonywania obliczeń wytrzymałościowych,

- 3D - opracowanie projektu w formie trójwymiarowej uzupełnione elementami dokumentacji, ułatwiającej prowadzenie prac wykonawczych,

- 4D - poziom 3D uzupełniony o pełną informację na temat zarządzania budową (rys. 10),

- 5D - poziom 4D połączony z kosztorysowaniem i z podstawowymi informacjami o wewnętrznych systemach w budynku,

- 6D - poziom 5D uzupełniony o analizy efektywności energetycznej,

- 7D - funkcjonalności z poziomu 6D oraz dodatkowo zasady zarządzania budynkiem podczas eksploatacji.

W przyszłości można oczekiwać, że połączenie umiejętności współpracy i zarządzania zasobami ludzkimi wraz z odpowiednimi narzędziami informatycznymi spowoduje znaczne ograniczenie czasochłonności inwestycji budowlanych i kosztów na nie ponoszonych.

\subsection{Bezpieczeństwo pracy $w$ budownictwie}

Budownictwo jest w czołówce branż, w których występują wypadki. Na rys. 11 pokazano liczbę wypadków w budownictwie $\mathrm{z}$ lat 2011-2014 na podstawie pracy [18]. W tej samej pracy podano, że 43\% wypadków w latach 2011-2014 to były upadki z wysokości, w tym szczególnie z rusztowań budowlanych. Dlatego poniżej zagadnienie to zostanie opisane właśnie na przykładzie stosowania rusztowań budowlanych.

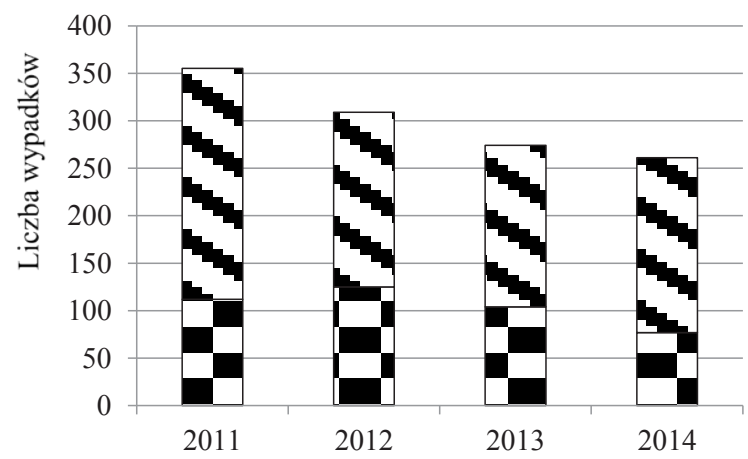

Rys. 11. Liczba wypadków, $\mathbb{N}$ - wypadki śmiertelne, $\mathcal{X}$ - wypadki z ciężkimi obrażeniami

Badania zaprezentowane w literaturze pokazują, że problem wypadków na rusztowaniach jest problemem międzynarodowym. Na przykład według pracy [19] w Wielkiej Brytanii w latach 1989-1993 było 3738 upadków z rusztowań, 1304 wypadków spowodowanych upadkiem narzędzi z rusztowań, a 345 było związanych z upadkiem samych rusztowań. Według tego samego artykułu [19] z przeprowadzonych w latach 1997-2000 badań na 62 rusztowaniach wynika, że wypadki w Wielkiej Brytanii były spowodowane: błędami konstrukcyjnymi $-48.4 \%$, brakiem zabezpieczeń - $14.5 \%$, niewłaściwym posadowieniem - 
$6.4 \%$, błędami ludzkimi - 6.4\%, złym stanem technicznym rusztowania $-16.1 \%$, przeciążeniem konstrukcji $-8.2 \%$. W artykule [20] przedstawiono problemy, związane z ryzykiem pracy na rusztowaniach, jakie występują w Stanach Zjednoczonych. W roku 2000, na 5915 wypadków na budowach w USA, 734 to były upadki z rusztowań, a wśród tych upadków 85 było bezpośrednio związanych z awarią rusztowań.

Rusztowania charakteryzują się też różnorodnością ze względu na materiał, z którego mogą być zrobione, oraz ze względu na stosowane rozwiązania technologiczne. Ze względu na materiał rusztowania można podzielić na stalowe, aluminiowe, bambusowe i drewniane. Natomiast ze względu na stosowane rozwiązania technologiczne oraz stosowane elementy konstrukcyjne rusztowania budowlane dzielimy na: rurowe, warszawskie, ramowe (fasadowe), modułowe, przejezdne i wieżowe. Nowoczesne systemy rusztowań pozwalają na dowolne kształtowanie konstrukcji a ich złożoność pokazano na dwóch przykładach na rys. 12 .

a)

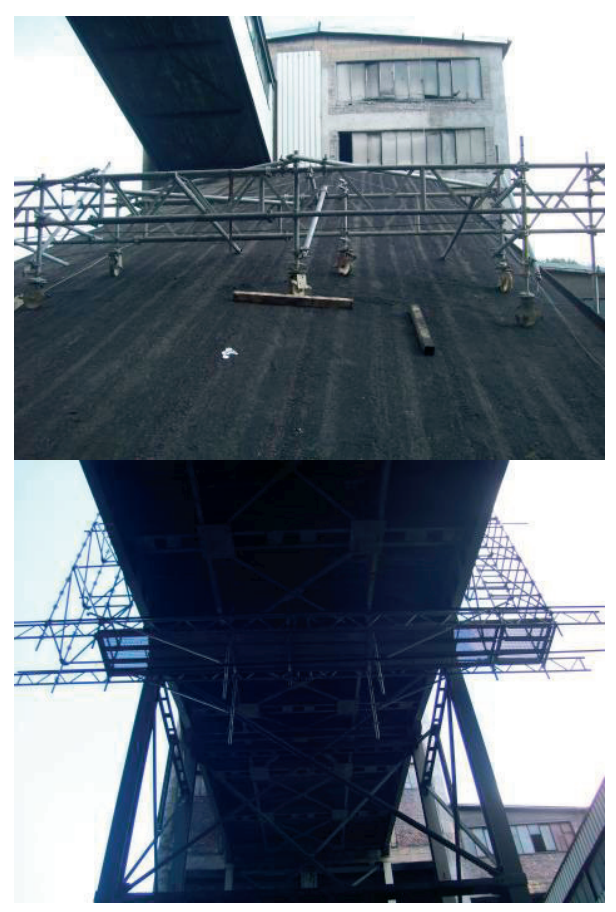

b)

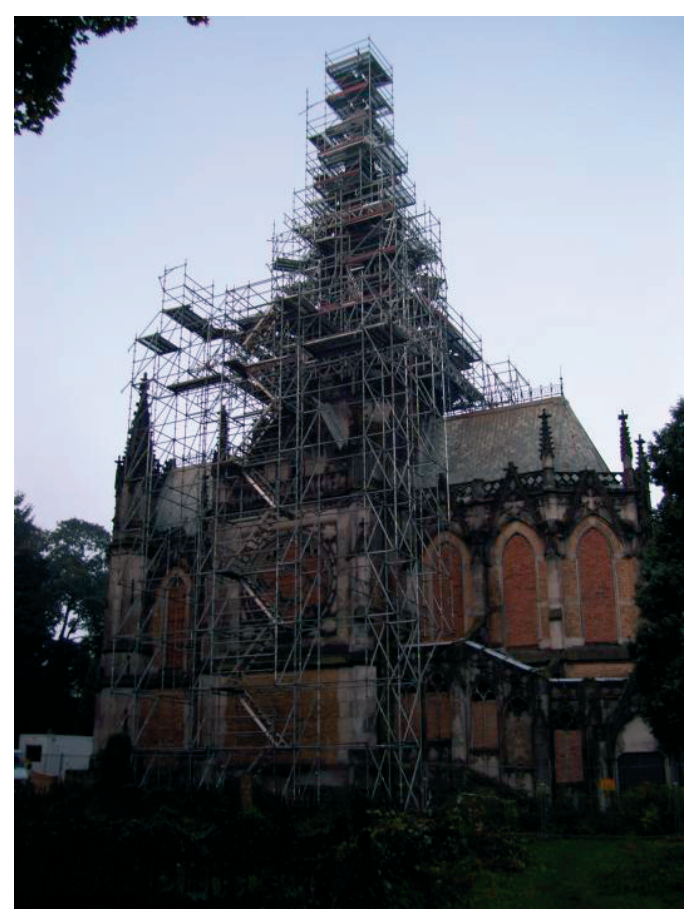

Rys. 12. Przykłady rusztowań: a) rusztowanie wokół mostu przekaźnikowego w KWK Ziemowit, b) rusztowanie wokół Kaplicy Scheiblera w Łodzi.

Na rys. 13 pokazano etapy funkcjonowania rusztowania. Wypadki występują w trzech ostatnich etapach, tzn. podczas montażu, eksploatacji i demontażu. Jednak na bezpieczeństwo pracy mają wpływ zarówno trzy etapy poprzedzające użytkowanie rusztowań, jak i samo użytkowanie. Zmniejszenie wypadków przy pracy, związanych z użytkowaniem rusztowań, wymaga zwiększenia kultury bezpieczeństwa wśród inżynierów i wiedzy w zakresie konstruowania i prawidłowego użytkowania rusztowań. 


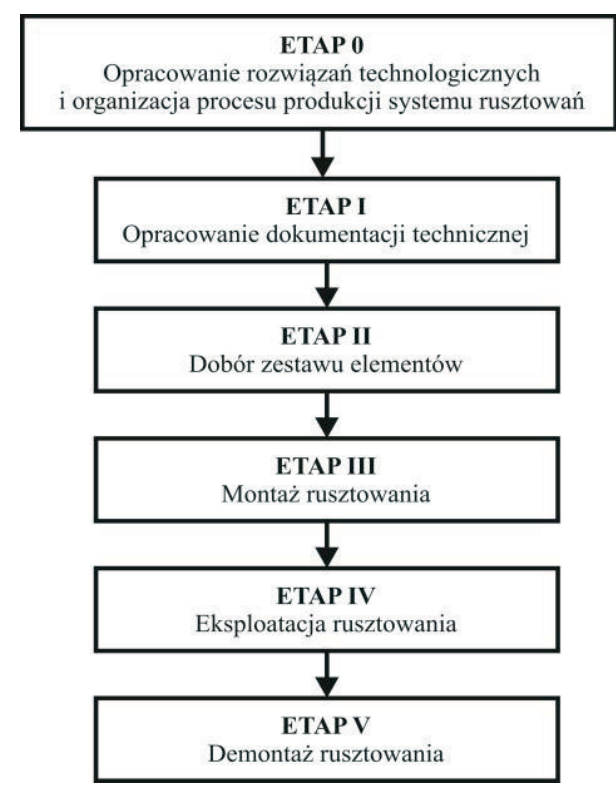

Rys. 13. Etapy funkcjonowania rusztowania [18]

\subsection{Wzajemne poszanowanie w pracy oraz stosowanie zasad etyki i ogólnie dobrych praktyk}

Bardzo dużym problemem w budownictwie jest stosowanie dobrych praktyk w biznesie. W artykule [21] opisano problem zadłużenia firm budowlanych. W marcu 2016 roku zadłużenie firm odnotowane w Krajowym Rejestrze Długów (KRD) w tym dziale gospodarki wynosiło 1,35mld zł. Przedsiębiorstwa budowlane były winne instytucjom ubezpieczeniowym i finansowym $400 \mathrm{mln}$ złotych, firmom handlowym były winne 384,9 mln zł, a pozostałe zadłużenie to w większości zadłużenie pomiędzy firmami budowlanymi. Jedne firmy nie płacą innym firmom budowlanym i nakręca się w ten sposób zadłużenie, często kończące się upadkiem przedsiębiorstw. Dług firm budowlanych często wynika z tego, że to one są wierzycielami. Zobowiązania wobec firm budowlanych w KRD wynosiły w marcu 2016 roku $565 \mathrm{mln}$ zł. Poziom wzajemnego zadłużenia pokazuje, że polityka i zasady dobrego zarządzania nie są rozpropagowane wśród kadry zarządzającej budownictwem i należy w tym kierunku podjąć działania między innymi poprzez wprowadzenie odpowiednich treści w nauczaniu.

\section{Posumowanie}

W pracy zaprezentowano przekrój zakresu wiedzy, którą musi posiadać obecnie inżynier budownictwa, na podstawie studiów przypadków i wybranych problemów inżynierskich. Inżynier budownictwa obecnie musi zdawać sobie sprawę z tego, że wiedza, którą powinien posiadać, w bardzo szybkim tempie się zmienia i jest coraz obszerniejsza. Dyscyplina budownictwo staje się obszarem łączącym problemy z wielu innych dyscyplin pokrewnych (architektura, inżynieria środowiska, elektrotechnika, automatyka i robotyka, informatyka) oraz z innych dziedzin nauki (nauki o ziemi, nauki biologiczne, nauki ekonomiczne, nauki humanistyczne). Dlatego studia II stopnia na kierunku Budownictwo powin- 
ny uwzględniać kierunki rozwoju technologii, materiałów, rozwiązań konstrukcyjnych i metod zarządzania procesami inwestycyjnymi oraz wskazywać studentom tendencje w tym zakresie. Ponadto powinny przekazywać taki zasób wiedzy, aby z jednej strony uświadomić inżynierowi, jak ważny jest jego zawód dla społeczeństwa a z drugiej strony mógł być podstawą właśnie do tego dalszego samodzielnego poszerzenia wiedzy.

\section{Literatura}

1. Lis P. Zapotrzebowanie gospodarki na energię i energochłonność eksploatacyjna budynków. Budownictwo o zoptymalizowanym potencjale energetycznym (2011) 145-163.

2. Szczechowiak E. Uwarunkowania unijne $i$ polskie $w$ zakresie efektywności energetycznej obiektów i procesów energetycznych. Ciepłownictwo, Ogrzewnictwo, Wentylacja 10 (2007) 27-33.

3. Cabeza L.F., Navarro L., Barreneche C., de Gracia A., Fernández A.I. Phase-change materials for reducing building cooling needs. Eco-efficient Materials for Mitigating Building Cooling Needs. Design, Properties and Applications (2015) 381-399.

4. Kenisarin M., Mahkamov K. Passive thermal control in residential buildings using phase change materials. Renewable and Sustainable Energy Reviews 55 (2016) 371-398.

5. Pisello A.L., Castaldo V.L., Cotana F. Dynamic thermal-energy performance analysis of a prototype building with integrated phase change materials. Energy Procedia 81 (2015) 82 88.

6. Sbar N.L., Podbelski L., Yang H. M., Pease B. Electrochromic dynamic windows for office buildings. International Journal of Sustainable Built Environment 1 (2012) 125-139.

7. Tavares P.F., Gaspar A.R., Martins A.G., Frontini F. The impact of electrochromic windows on the energy performance of buildings in Mediterranean climates: a case study. Eco-efficient Materials for Mitigating Building Cooling Needs (2015) 499-524.

8. Pittaluga M. Electrochromic glazing and walls for reducing building cooling needs. Ecoefficient Materials for Mitigating Building Cooling Needs (2015) 473-497.

9. Gabel J., Carver M., Gerometta M. The Skyscraper Surge Continues in 2015, The "Year of 100 Supertalls", Tall Buildings in Numbers - 2015: A Tall Building Review. Council on Tall Buildings and Urban Habitat, 9-10.

10. Ksit B., Waltrowska M. Budynki wysokie zrównoważone ekologicznie. Inżynier budownictwa, http://www.inzynierbudownictwa.pl

11. Gensler, Gensler Design Update: Shanghai Tower, Gensler Publications, 2010.

12. Rozporządzenie Ministra Infrastruktury z dnia 12 kwietnia 2002 r. w sprawie warunków technicznych, jakim powinny odpowiadać budynki i ich usytuowanie, Dz.U. $2002 \mathrm{nr} 75$ poz. 690.

13. Orłowski Z., Szklennik N. Zakres modernizacji budynku - jako wynik analizy diagnostycznej obiektu. Civil and Environmental Engineering 2 (2011) 353-360.

14. Kozicki J. Nowe rozwiazania w modernizacji zabytkowych obiektów pofabrycznych. Mat. konf. „Nowoczesne technologie w budownictwie - wybrane zagadnienia”, 3-4 marca 2016, Łódź.

15. Rozporządzenie Ministra Nauki i Szkolnictwa Wyższego z dnia 2 listopada 2011 roku w sprawie Krajowych Ram Kwalifikacji dla szkolnictwa Wyższego, Dz. U. 253, poz. 1520.

16. Dokumentacja planu studiów i programu kształcenia, kierunek Budownictwo, studia stacjonarne II stopnia, profil ogólnoakademicki, Wydział Budownictwa i Architektury Politechniki Lubelskiej, czerwiec 2014.

17. Majchrzak Ł. Zarządzanie procesem inwestycyjnym i życiem obiektu w oparciu o nowoczesne technologie informatyczne. Mat. konf. „Nowoczesne technologie w budownictwie - wybrane zagadnienia", 3-4 marca 2016, Łódź.

18. Błazik-Borowa E., Czarnocki K., Dąbrowski A., Hoła B., Misztela A., Obolewicz J., WalusiakSkorupa J., Smolarz A., Szer J., Szóstak M. Bezpieczeństwo pracy w budownictwie, Wydawnictwo Politechniki Lubelskiej, Lublin 2015. 
19. Whitaker S.M., Graves R.J., James M., McCann P. Safety with access scaffolds: Development of a prototype decision aid based on accident analysis. Journal of Safety Research 34 (2003) 249-261.

20. Halperin K. M., McCann M. An evaluation of scaffold safety at construction sites. Journal of Safety Research 35 (2004) 141-150.

21. Depesze: KRD: zadłużenie branży budowlanej sięga blisko 1,35 mld zł, Gazeta Wyborcza, http://wyborcza.pl/1,91446,19711005,krd-zadluzenie-branzy-budowlanej-siega-blisko-1-35mld-zl.html, 6 marca 2016.

\title{
Challenges in the construction industry and teaching civil engineers
}

\author{
Ewa Blazik-Borowa \\ Department of Structural Mechanics, Faculty of Civil Engineering and Architecture, \\ Lublin University of Technology,e-mail: e.blazik@pollub.pl
}

\begin{abstract}
This paper discusses problem of the scope of education of civil engineer during intensive development of technology, increased requirements for buildings and the growth of social expectations with regard to people performing independent technical functions. This paper discusses exemplary solutions which decrease energy consumption of buildings, designing and erecting of high buildings taking into account aspect of sustainable development, revitalization technology of monuments, which lost their function due to social transformations, principles of cooperation between the industries and problems of responsibility of civil engineer for teams they are working with.

Keywords: professional qualifications, engineering problems, modern technologies, the ethics of the civil engineer profession.
\end{abstract}


